\title{
LHFPL6 Gene
}

National Cancer Institute

\section{Source}

National Cancer Institute. LHFPL6 Gene. NCI Thesaurus. Code C97607.

This gene may play a role in cell adhesion or cell proliferation. 